\title{
RULES FOR THE TRANSFER OF WEAPONS AND MILITARY TECHNOLOGY IN THE LIGHT OF CONTEMPORARY INTERNATIONAL LAW
}

\author{
Piotr MILIK, PhD \\ War Studies University, Warsaw, Poland \\ e-mail: p.milik@akademia.mil.pl
}

\begin{abstract}
This study investigates the contents of key documents of international rank regulating the transfer of weapons and military technologies in order to mark the principles that rule this kind of state activity. The following principles have been pointed out: the principle of minimizing the consumption of the world's human and economic resources for armaments; the principle of respect in the transfers of weapons and the principles of the Charter of the United Nations; the principle of transparency in the transfer of weapons and military technology; the principle of limitation of armaments as a factor constituting a threat to peace and national, regional and international security; the principle of the regulation of transfer of weapons in the domestic law of states; and the principle of respect for humanitarian law and human rights in international military transfers.
\end{abstract}

Keywords: arms trade, arms transfer, international law, military technology,

\section{Introduction}

This article analyses a wide range of international regulations, both of a political and legal nature, in the area of transfer of weapons and military technologies with regard to their basic types, which allow the rules for transfers of weapons and military technologies which are guided by the state and the international community in the course of the so-called "special trade" to be distinguished as: 
the principle of minimizing the consumption of the world's human and economic resources for armaments; the principle of respect in the transfers of weapon and the principles of the Charter of the United Nations; the principle of transparency in the transfer of weapons and military technology; the principle of limitation of armaments as a factor constituting a threat to peace and national, regional and international security; the principle of the regulation of transfers of weapons in domestic law of states; and the principle of respect for humanitarian law and human rights in international military transfers.

These rules for the international trade in arms are mostly political in nature, which means they don't constitute legally binding rules from the point of view of international law. Despite this, states wishing to pursue their political commitments in the area of "special trade" and wishing to maintain international peace and security implement these internationally agreed policy principles into their internal legal order. Thus they shape their internal legislation in line with rules agreed jointly with other states. Forming the internal legislation of the states in this way contributes to the development of common, universally accepted rules of customary international law. In other words, international documents of a political nature governing "special trade" don't constitute binding rules of international law, but contribute to shaping the practice of states in this area resulting directly in their internal laws and, therefore, helps shape the norms of customary international law.

\section{The principle of minimizing the consumption of the world's human and economic resources for armaments}

The principle of minimizing the consumption of the world's human and economic resources for armaments was expressed for the first time in 1945 in the Charter of the United Nations, in its article 26, which stated that "In order to promote the establishment and maintenance of international peace and security with the least diversion for armaments of the world's human and economic resources, the Security Council shall be responsible for formulating, with the assistance of the Military Staff Committee referred to in Article 47, plans to be submitted to the Members of the United Nations for the establishment of a system for the regulation 
of armaments." For this article, the latter documents regulating the circulation of arms and military technologies in relations between states were referenced, in particular the document entitled "Principles of trade in conventional arms" adopted on 25 November 1993 in Vienna at the 49th plenary meeting of the Special Committee of the CSCE Forum for Security Cooperation ${ }^{2}$ and Arms Trade Treaty of June 3, 2013. This principle is confirmed by the European Union Code of Conduct on Arms Exports adopted by the EU Council of General Affairs on 8 June 1998. The Code formulates the criterion of conduct for EU member states on the compliance of exported weapons with the technical and economic capacity of the recipient country, taking into account the demand that states should meet their legitimate security and defence needs with the least disparity between the level of armament and economic resources. The EU member states were obliged to take into account whether. in the light of information from relevant sources (reports of the United Nations Development Programme - UNDP, the International Bank for Reconstruction and Development - IBRD, International Monetary Fund IMF, the Organisation for Economic Cooperation and Development - OECD), the proposed export would seriously hamper the current development of the recipient country. In this context, EU member states must consider, in particular, the level of military spending and welfare of the recipient country, taking into account the possible assistance of the European Union or member states. The basic statutory document of the Wassenaar Arrangement, the so-called "Initial Elements", constructs, in this context, the principle of balancing the interests of political, social and economic countries in trade in arms and dual-use goods. At the same time, within the framework of cooperation between states implemented under the Wassenaar Arrangement, a document entitled "Elements for objective

1 The legal nature of the documents adopted at the CSCE /OSCE is problematic. It is assumed that by the time the functioning of the CSCE as a form of multilateral diplomacy conference was adopted in the framework of its meetings, the documents were of the nature of the international agreements (e.g. The Treaty on Conventional Weapons in Europe, the Treaty on the free skies), or non-legally binding political statements (all other documents were not given the rank of an international agreement by the state).

2 CSCE Forum for Security Cooperation is one of the main decision-making bodies of the CSCE/OSCE brought to life at the Helsinki summit in 1992. The Forum has authority on the issue of arms control and disarmament, arms transfers and military technologies, dispute settlement mechanisms, and aspects of political safety. This body meets weekly. The presidency of the deliberations is given to each of the 56 OSCE participating states for four consecutive months. Decisions are made by consensus. 
analysis and advice concerning potentially destabilising accumulations of conventional weapons" was adopted on December, 3rd, 1998. This document states that the country should consider carrying out the transfer of weapons and military technologies with the objective of minimising the consumption of the world's human and economic resources for armaments.

At the core of the principle of minimizing the consumption of the world's human and economic resources for armaments lies the idealistic belief that the efforts of states and their populations, economic potential and natural resources, and technological and industrial base can be used for greater benefit, if they are properly targeted, in particular, for investments infrastructure (transport, sanitation, utilities, educational, cultural, etc.), which may contribute to the development and well-being of countries, societies and human populations. This view was expressed in 1945, just after the Second World War, which brought death and destruction to millions of people around the world and was perceived by the broad masses who experienced by the war as madness unleashed by blind lust for conquest and domination by dictators standing at the head of criminal regimes, and this view seems to be justified. Idealism, in particular the belief in the possibility of creating a world without war, associated suffering, poverty and social fragmentation, a world based on the principle of peaceful coexistence of states and peoples and sustainable development constitute the foundation of the United Nations and the driving force for the reconstruction of the civilised world, particularly in Europe from the devastation of war. ${ }^{3}$

This view is reasonable justification only on condition that the world will be one system of connected elements, where it will be possible to peacefully co-exist in societies with a similar level of development and prosperity (which is a result of the proposed sustainable development). Otherwise, the idea of minimizing societies focus on the production of armaments remains only an idealistic, populist fantasy (and dangerous if you treat it too literally).

3 The same idealistic assumptions underlying the post-war European integration of the Western world based on creating close and inseparable economic ties between states and European societies, whose bonds would lead to the creation of joint European political interests, blurring national divisions on the continent and building a federation of states who share common values (democratic model of governance, human rights, respect for the Christian tradition). 
In the modern world, organised on the model of the European nation-states into a mosaic which is the dominant form of political organisation of society, the states remain fundamental guarantors of the security of the population living in them. Although more and more boldly, in the era of globalisation some point to the progressive regional integration processes (European Union, African Union, other economic integration organisations such as the Southern Common Market - MERCOSUR, Organisation of South - East Asia - ASEAN, etc.) and the increased importance of large centres of urban life in contemporary societies for their welfare and safety ${ }^{4}$, nation states, nevertheless, remain the main administrators of sovereignty in the international arena, equipped with military strength and showing the political cohesion necessary for its use.

According to the findings of A. H. Maslow in the catalogue of our needs, the need for security is second only after physiological needs such as the need for sleep, satisfy hunger and thirst, etc. ${ }^{5}$ in determining our behaviour as human individuals and societies. Implementation of all other individual and social needs must be pushed into the background. The need for security should be implemented above all through participation in the political structure which is the national state that possesses military force. The existence of the state determines the further implementation of the demands and needs of individuals and societies.

As follows from the above findings, despite ongoing globalisation bringing new trends and challenges, the nation state remains the primary entity that meets the fundamental need for security of individuals and human populations. Therefore, at the state level, decisions are made on the allocation of financial resources and expeditious use of human and economic resources for armaments production, to meet the vital security interests of the population living in the state. The state appoints bodies to analyse threats to its security, for the security of its citizens, and decides to take action and allocate funds to eliminate and minimise these

4 See R. Florida, The Rise of the Creative Class and How It's Transforming Work, Leisure, Community and Everyday Life, Basic Books Publishing House 2002, (polish edition: Narodziny klasy kreatywnej, Wydawnictwo Narodowe Centrum Kultury 2010), E. Glaeser, Triumph of the City, Macmillam Publishing House 2011, or B. Barber, If Mayors Ruled the World: Dysfunctional Nations, Rising Cities, Yale University Press 2013 (polish edition: Gdyby burmistrzowie rzadzili światem, Wydawnictwo Muza S.A. 2014).

5 A. Maslow, A Theory of Human Motivation, Psychological Review, 1943, Vol. 50/4, p. 370-396. 
risks. ${ }^{6}$ In such a modern model of social organization, can armaments production for investment in infrastructure, investment in education and culture on a global scale within the general (collective) security system be reduced? Such actions are possible only when individual countries evaluate the individual, particularistic perspective, according to the principles of praxeology, that the degree of safety allows resources from the defence sector (military) to be allocated to other sectors of the state economy.

States can also be involved in arms reduction and disarmament when assessing that it is necessary to alleviate the tensions between them. Such a situation occurred in East - West relations during the Cold War, when the states that were concentrated in two hostile military blocs and involved for decades in the arms race decided to reduce tension in bilateral relations and reduce the threat of armed conflict with the use of atomic weapons, in which the potential losses on both sides could not offset the expected victories, and even could lead to the annihilation of the human race due to the massive use of nuclear weapons held by the superpowers. But, even in this case, the driving force behind the country was not rational allocation of resources spent on armaments to other sectors of the economy, education and culture, but rather a desire to improve the subjective feeling of safety of the population by reducing the threat of nuclear conflict.

6 In the science of international relations, the concept of human security appears increasingly often, which is a manifestation of a broader view of safety, a sign beyond the category of national security. The formulation of the concept of human security is a distinction between national security and the safety of its citizens in a situation when the state does not work for their welfare and development. Also, security sciences notice the diversity of types of security depending on the subjects highlighting national security, social security, and security of the state. R. Zięba points on this occasion to unmilitarising, expanding the scope and content of the security (see R. Zieba, O tożsamości nauk o bezpieczeństwie, AON Scientific Papers, No. 1 (86) 2012 p. 7 - 22). The tendency, in the discussion about security, to go beyond the circle of concepts related closely with the military security of the state appeared in the 1990s with the completion of the global nuclear power rivalry and offset by the wayside threat of war between the great powers and countries allied with them focused on hostile military blocs. The world was then faced with new challenges, which could include an increase in the number of armed conflicts of an internal nature, the severity of the new forms of international terrorism, mass migrations, and the deepening economic stratification on a global scale. See on this subject: G. Michałowska, Bezpieczeństwo ludzkie, [in] Świat wobec wspótczesnych wyzwań i zagrożeń, Symonides J. (ed.), Wydawnictwo Naukowe Scholar, Warsaw 2010, p. 227 - 234. 
This does not change the fact that the arms race, which the world experienced during the Cold War, involving a huge financial outlay for the acquisition of military technology and armament production by all of the participants in the race, contributed to the collapse of the Soviet Union, the model of centrally planned economy that couldn't manage to reduce its expenditure on thearms race, which ultimately led to the economic collapse, political crisis and, ultimately, collapse of the USSR. The arms race was used by the United States as a form of struggle against the communist bloc countries with the Soviet Union at their head, which proved to be effective at the end of the Cold War.

We can also point at the doctrine of political realism, where we can find the views that nuclear technology and the availability of nuclear weapons have contributed to the maintenance of peace in Europe and in the world after the Second World War. Kaczmarski M. writes: "With regard to nuclear weapons, most researchers recognise their further proliferation as carrying major risks (while acknowledging its stabilising role in the relations between the great powers, especially during the "Cold War"). However, the negative impact of the proliferation of nuclear weapons for international security is not so obvious in academic debate. Some authors (especially associated with political realism, such as Kenneth Waltz) recognise that the increase in the number of countries possessing nuclear weapons contributes more to the stability of international relations."

It should also be noted that safety defined as freedom from threats is sometimes understood as a purely subjective, psychological phenomenon. ${ }^{8}$ Security is understood as the subjective feeling of absence of risk. For such a subjective sense consists of a number of factors conditioned by the availability of information, life experiences of human beings and the historical experiences of societies etc. Thus, the objectification of security, which is based on measurable indicators and data showing no real threat, does not exist. Such data and indicators can only contribute to the construction of a subjective sense of security of individuals and societies, which in democratic countries have the ability to influence the

7 M. Kaczmarski, Problem proliferacji broni masowego rażenia, [w:] Świat wobec wspótczesnych wyzwań i zagrożeń, J. Symonides (ed.), Wydawnictwo Naukowe Scholar, Warszawa 2010, p. 375.

8 Z.J. Pietraś, Podstawy teorii stosunków międzynarodowych, UMCS, Lublin 1986, p. 162. 
political decisions of state authorities. ${ }^{9}$ Assuming the definition of security as the subjective feelings of an entity performing its vital interests, feelings not always based on the actual, really existing premises or premises incorrectly estimated due to lack of information, misinformation or an irrational, emotional approach, the implementation of the idea of minimising the consumption of human and economic resources for armaments globally, with the purpose of allocation of these factors to other sectors of the economy, education and culture seems to be impossible.

On the basis of Polish law, the key documents setting out the responsibilities of private entrepreneurs on national defence are the Act of August 23, 2001 on organising tasks for state defence implemented by entrepreneurs (Journal of Laws. 2001 No. 122, item. 1320) and the Act of November 21, 1967 on the common duty to defend the Polish Republic (Journal of Laws. 1967 No. 44, item. 220).

The law on the organisation of tasks for state defence implemented by entrepreneurs determine the rules for organising such tasks by entrepreneurs doing business on Polish territory, including the entrepreneurs of special importance for the economy and defence ${ }^{10}$, indicating government bodies who have the right to organise and supervise execution of these tasks, and the financing.

In the Law on the common duty to defend the Republic of Poland, the task of strengthening the defence of Poland, to prepare the population and property in the

9 An example illustrating this phenomenon could be the withdrawal of Spanish troops from Iraq after the terrorist attacks in Madrid carried out on March 11, 2004, with the intention of intimidating Spanish society and discouraging them from continuing to participate in a military coalition with the United States and Great Britain. The attacks frightened people going to the parliamentary elections and they elected socialists who campaigned in their election programme for the immediate withdrawal of Spanish troops from Iraq. Their election promise has been kept. The state decided (indirectly, through the act of election) under the influence of intimidation of Spanish society, not guided in this regard, rational indications of the need for participation in the anti-terrorist coalition, in order to create a coherent front against the terrorist threat common to the entire Western World.

10 Entrepreneurs of special importance for the economy and defence are listed in the ordinance of Council of Ministers dated October 4, 2010 r. (Journal of Laws. 2010. No. 198, item. 1314). This regulation lists 200 business entities in the following areas: operation of airports and seaports, radio broadcasting and television production, transport and storage of petroleum products, production, renovation or modernisation of armaments and military equipment, the special trade, transport services, postal services, telecommunications, manufacturing, distribution and transmission of natural gas, liquid fuels and electricity. 
event of war and perform other tasks within the general defence duty, was imposed on all public authorities and public administration, local government authorities, as well as businesses and other organisational units, social organisations, and also every citizen in the range specified in the laws.

The Act on common duty to defend the Republic of Poland formulates three types of obligation of benefits for the defence: the provision of personal benefits, in kind benefits and special benefits.

For those with Polish citizenship who are over 16 and no older than 60 years of age, an obligation can be imposed to perform various types of ad hoc work for the preparation of national defence or to combat natural disasters and the liquidation of their consequences.

At offices and state institutions, entrepreneurs and other organisational units and individuals a benefit in kind obligation can be imposed, consisting in the use of their real estate and movable property for the purpose of preparing the defence of the state.

The law also formulates a duty called special benefits that may be imposed on local bodies of government administration, state institutions, local government authorities and entrepreneurs and other organisational units. Special services rely on the adaptation of owned real estate and movables for the needs of national defence; adaptation of buildings and manufactured movables for the needs of national defence and the collection, storage and maintenance items needed for the abovementioned activities.

Legislation has not been passed to minimise the consumption of domestic human and economic resources for armaments, or more broadly on the Polish defence effort in either of the two major, above analysed laws defining the obligations of entrepreneurs towards the defence of the state.

This is not mentioned in the basic state documents relating to national defence and security, such as the "National Security Strategy of the Republic of Poland" November 5, 2014 (Approved by the President at the request of the Prime Minister on the basis of article 4a. 1. point 1. Act on the common duty to defend the Polish Republic dated November 21, 1967), or the "Development strategy of the national security system of the Republic of Poland 2022" (adopted by resolution of the 
Council of Ministers at April 9, 2013, at the request of the Minister of National Defence, Polish Monitor of May 16, 2013, No. 337).

In the introduction to the "National Security Strategy of the Republic of Poland", it is stated that "the Strategy as a whole recognises the issues of national security and shows how to use all the resources at the disposal of the state in the defence, protection, social and economic sphere in optimal ways." The term "optimal ways" was used to distinguish the use of human and material resources for the needs of national security. Optimal use of resources means their use as such, which will provide maximum security with the minimum involvement of forces and means. There is not, however, any reference to the principle on the basis of international law to minimize the effort for defence (in the dimension of arms production) and to allocate human and material resources to other sectors of the economy, education and culture.

Polish documents are definitely closer to the principle of balancing the interests of political, social and economic countries in trade in arms and dual-use goods expressed in the Wassenaar Arrangement than the idea of minimising the consumption of the world's human and economic resources for armaments.

\section{The principle of respect in weapon circulation in the purposes and principles of the Charter of the United Nations}

The principle of respect in weapon circulation in the purposes and principles of the Charter of the United Nations mentions the CSCE document "The principles of trade in conventional arms" of November 25, 1993. In addition, the Arms Trade Treaty of June 3, 2013 points out in the first task of its preamble the need for states to adhere to the purposes and principles of the Charter of the United Nations. In paragraph 5 of the preamble, the Arms Trade Treaty makes reference to the statement that peace and security, development and human rights are the pillars of the United Nations system and the foundations of collective security. The Arms Trade Treaty subsequently lays down the principles to be followed by State Parties in the mutual trade in arms and military technologies, among which 
the first listed principle is the principle of respect for the inherent right of all states to individual or collective self-defence. Reference is made at the same time to art. 51 of the Charter of the United Nations. Further, the principles set out in the Treaty on arms trade refers to the settlement of international disputes by peaceful means, refraining in their international relations from the threat or use of force against the territorial integrity or political independence of any state, and non-interference in the internal affairs of states. This is followed each time by a reference to the relevant provision of the Charter of the United Nations.

The principle of respect for the trade in arms and dual-use goods and the inherent right of all states to individual or collective self-defence forms the so-called "initial elements" (fourth goal) of the basic statutory document, the Wassenaar Arrangement. The European Union Code of Conduct on Arms Exports was also adopted by the EU Council of General Affairs on June 8, 1998. In its preamble, it mentions the need to respect the principle of individual or collective selfdefence in the circulation of weapons. The CSCE document "The principles of trade in conventional weapons" refers to it, as mentioned, at the beginning of the document.

Regarding the purposes and principles of the Charter of the United Nations on the issue of trafficking in arms and military technologies (both conventional and nuclear), it should be noted first that the rotation of such should not favour fuelling the situation threatening international peace and security and should not frustrate the collective efforts of the United Nations adopted to prevent threats to peace and security, or to suppress all acts of aggression or other breaches of the peace.

The question is whether the arms trade (and other forms of transfers in arms and military technology) can reconcile with the idea of not stirring up a situation threatening international peace and security. On the one hand, a simple thought can be mentioned that the lack of resources to fight in the form of weapons, ammunition and military technology effectively prevents aggressive nations initiating armed conflict. On the other hand, possession of weapons and military technology, including weapons and nuclear technology, is not prohibited in international law. We can say further that possession of a proper military arsenal guarantees the safety of countries in the event of armed attack. Therefore, safe trafficking in weapons is not in contradiction with the basic aim of the Charter of 
the United Nations for maintaining international peace and security. The old Latin maxim says: si vis pacem, para bellum (want peace - get ready for war). Article 8 of the Covenant of the League of Nations of June 28, 1919 stated that the maintenance of peace requires the reduction of national armaments to a minimum, consistent with national security and with the enforcement of international obligations by joint action. At the same time, members of the League pledged to give each other honest and comprehensive information on the progress of their arms, military, sea and air programmes, and the status of these industries, which can be adapted for military purposes.

The idea of universal disarmament, which on many occasions is lifted, was merely transferred to international relations from the internal order of many countries which deliberately disarmed their citizens and passed the monopoly of the use of force into the hands of the authorities and state services. The condition for the effectiveness of such a model is the appropriate state structures and the efficiency of their operations. On the basis of international relations in their present form, to achieve the aim of universal disarmament is not possible precisely because of the lack of an organised apparatus of coercion, which would provide sufficient security to the members of the international community.

In practice, it is difficult to assess unequivocally whether, in the circumstances, the transfer of weapons ensures the security of states and the stability of the international situation, or whether it contributes to the escalation of tension in relations between states. This is because the will of the states to purchase weapons intensifies when they notice increased threats to their security. This kind of demand for weapons and military technologies immediately finds an answer in the form of the supply carried out in the weapons trade, not only by state-owned companies directly dependent on governments, but also by private operators, which are, to a limited extent, within the control of the state. On the one hand, we are dealing with conscious and deliberate state suppliers of weapons and military technology support through the transfer of arms to states and non-state political movements, which are transferred in the belief that the supplier country is pursuing its security policy. On the other hand, the lack of proper control over private entrepreneurs operating in the special trading sector, where supervision is not easy to reconcile with the principle of freedom of economic activity, may ultimately result in the escalation of tension in international relations. While it is not always possible 
to determine whether the transfer of weapons is carried out deliberately by the state and fully controlled by the state, or carried out beyond the knowledge and the will of the state by private entrepreneurs, or even carried out by criminal organisations. Penetration into the sphere of arms trade is official state activity, the activity of their secret services, which, because of national security, is not disclosed. The activities of organised criminal groups that may serve as a tool of manipulation in the hands of the secret service creates a grey zone in which it is very difficult to provide clear criteria for state responsibility for the transfers.

The question is whether the practice of the international arms trade in itself is not in contradiction with the principle of the Charter of the United Nations stating that all UN members shall refrain in their international relations from the threat or use of force against the territorial integrity or political independence of any state, or in any other manner inconsistent with the purposes of the United Nations. The question concerns the scope of the term "threat of force". It seems that this concept should be interpreted narrowly, literally, for example the threat of use of force directly expressed an intention to make an armed intervention or armed attack. There may not be a threat of force itself in acquiring military equipment. The idea of refraining from the threat clearly means not directing aggressive behaviour towards another state.

We can also note on this occasion that in contemporary international relations, the use of force does not necessarily mean solely the use of armed force. The use of force can rely on the use of the advantages of economic and industrial potential, and cultural pressures. This understanding of the concept of "use of force" was certainly not the intention of the creators of the United Nations Charter, which does not change the fact that the common consent of the Member States of the United Nations and its organs can give old concepts new meanings. Although today we can give the notion of "use of force" wider meaning than was accepted by the authors of the Charter of the United Nations, in the official documents of international rank, which define the concept of aggression (the crime of aggression) as certainly linked with the concept of the use of force, only the use of 
armed force against the sovereignty, territorial integrity or political independence of another state is mentioned. ${ }^{11}$

It is extremely difficult to determine whether the transfer of weapons and military technologies in regions of the world with a tense political situation, threatening the outbreak of armed conflict, contributes to the stabilisation of the situation in the regions and thereby promotes the maintenance of international peace and security. Key decisions in this field were transferred into the hands of the UN Security Council.

Among the principles set out in the Charter of the United Nations is the goal of Member States to support the efforts of the United Nations in any action taken in accordance with the Charter and simultaneously ordered to refrain from giving assistance to any state against which the United Nations is taking preventive or enforcement action. With regard to the matter of the international arms trade, the above rule will apply primarily in a situation in which the Security Council decides on an embargo on arms supplies to the country which threatens international peace and security.

We must also remember, however, that the Security Council itself is not always free of political involvement, often representing not only the interests of the international community (as we would like to believe) but the interests of the great powers (in particular the permanent members of the Council). For example, Security Council resolutions establishing a no-fly zone in an armed conflict of an internal nature, in which government forces clashed with armed rebels usually poorly equipped; although seemingly applying to both sides of the conflict, it really hits the government forces which have aviation. The rebels can rarely demonstrate possession of the most technologically advanced weapons. Establishing a no-fly zone is clearly fuelling the rebellion and prolonging armed conflict, which could be otherwise quickly suppressed by government forces. However, that is the construction of internal governance of the United Nations, in which the nuclear

11 In this way, aggression was defined by the UN General Assembly Resolution of December 14, 1974 (RES 3314/1974) and by the Statute of the International Criminal Court of July 17, 1998 (Completed by 11 June 11, 2010, just about the definition of the crime of aggression on the revision conference in the capital of Uganda - Kampala). 
powers, the winners of the Second World War, are able to secure a special position resulting from their military potential.

The second main purpose of the United Nations is to build international relations based on the principles of equality of States and self-determination of peoples. The United Nations Charter states in the catalogue of its rules that the UN is based on the sovereign equality of all its members, and to refrain from intervening in matters which are essentially within the domestic jurisdiction of any state.

Equality of states is to give UN member states equal status under international law. It is an idea taken from the doctrine of internal law shaped in the era of the Enlightenment which talked about equality before the law for all citizens. Equality before the law does not mean the same rights and obligations in the international arena, but their distribution according to the potential of the country and their contribution to the maintenance of international peace and security. This principle establishes the right to treat entities that are in a similar situation equally, without discrimination. Hence, the special position in international law of the great powers, whose economic and military potential assume greater responsibility for the maintenance of international peace and security, while receiving the privilege of permanent membership in the UN Security Council.

The purpose of the United Nations relies on the development of friendly relations among nations based on respect for the principle of equal rights and selfdetermination of nations and is reinforced by the principle of non-interference in the internal affairs of states. The need to respect the principle of non-interference in the internal affairs of states is expressed directly in the Treaty on the arms trade from 2013. It talks about the fact that the state party will not intervene in matters which are essentially within the domestic jurisdiction of any other state, in accordance with article 2 paragraph 7 of the Charter of the United Nations.

The principle of sovereign equality of States at the time of its formulation in the Charter of the United Nations constituted a revolution in the relations between states and announced the coming of a new era without colonies and dependent territories. Prior to the Charter of the United Nations, the Covenant of the League of Nations did not go as far in the construction of the international order, although it also gave all Member States of the League one equivalent voice in the Assembly. 
The principle of the sovereign equality of states can be interpreted as guaranteeing countries equal, without discrimination, access to weapons and military technology under the condition of compliance with the objectives and principles of the Charter of the United Nations. Access to weapons and military technologies can be limited only because of the international security decision of the UN Security Council and other regional organisations, or indeed as a result of having limited state economic potential for not allowing the purchase of expensive weapons or modern technology.

A separate issue is to have a technology that allows the production and operation of chemical and bacteriological weapons, which were considered inhumane and prohibited, or nuclear weapons, access to which, due to their immense offensive potential, the international community is trying to suppress with non-proliferation agreements.

The principle of self-determination as a rule of operation of the international community is understood in international law ambiguously and, thus, is interpreted differently depending on the circumstances and political demands. The United Nations Charter is the first international agreement of a general nature which speaks of the principle of self-determination of peoples. According to art. 1 point 2 of the Charter, one of the purposes of the United Nations is: "To develop friendly relations among nations based on respect for the principle of equal rights and self-determination of peoples and to take other appropriate measures to strengthen universal peace." Art. 55, the opening chapter IX of the Charter, entitled "International economic and social cooperation" states: "In order to create conditions of stability and well-being necessary to maintain among the nations of peaceful and friendly relations based on respect for the principle of equal rights and self-determination of peoples, the United Nations support (...) ". The principle of self-determination of nations is, therefore, a basis for the development of friendly relations between nations firstly in the context of the objectives of the United Nations, and secondly in the context of provisions relating to international economic and social cooperation. No other provision of the Charter of the United Nations mentions the principles of self-determination. The UN Charter does not contain a precise definition, or even further specify the right of self-determination, but merely states that it is a basis for friendly and peaceful relations between nations. 
Detailing the principle of self-determination found its place in the International Covenant on Economic, Social and Cultural Rights of December 16, 1966. The principle of self-determination of peoples is contained in art. 1 of the Covenant: "All peoples have the right to self-determination. By virtue of that right, they freely determine their political status and freely pursue their economic, social and cultural development. To achieve its goals, all nations may freely dispose of their natural wealth and resources without prejudice to the obligations arising out of international economic cooperation, based on the principle of mutual benefit and international law. In any case, people cannot be deprived of their own means of subsistence. All State parties to the Covenant, including those with responsibility for the administration of dependent territories and trust territories, shall promote the realisation of the right of self-determination, and shall respect that right, in conformity with the provisions of the Charter of the United Nations...

In the cited document, a trend can be distinguished, which is perpetuated in the subsequent UN General Assembly resolutions on the right of nations to selfdetermination, and bound to the right of the pro-independence aspirations of the peoples in the colonies

The General Assembly resolution 2787 (XXVI) of December 6, 1971 entitled "Resolution on the importance of the universal realisation of the right of peoples to self-determination for the rapid granting of independence to colonial countries and peoples and the effective guarantee and observance of human rights" clearly linked the right of nations to self-determination with the right of colonial peoples to build their own state, "the General Assembly (...) calls upon all States faithful to the ideals of freedom and peace to grant full political, moral and material aid to nations struggling against colonial and foreign rule for liberation, selfdetermination and independence (... ..)."

As can be seen from the above, the right of peoples to self-determination was formulated after World War II in the basic documents of international rank and in the resolutions of the UN General Assembly as the law generally granted to colonial peoples and nations. Hence, there were interpretations that the law does not apply to nations, ethnic groups inhabiting the territory of the metropolis and the territories of existing states because it would be impossible to reconcile the right to self-determination of nations (meaning, for example, breaking away part 
of the country in order to establish there a separate political entity) with the right to territorial integrity of states.

On the other hand, in line with the long-standing historical practice of states, international law generally does not question the legality of uprisings, rebellions and struggles for independence waged on the territory of a state, which often tend to detach part of the national territory. International law even gives each state the right to recognise the rebellion forces fighting against the government for the belligerents or insurgents, which entails certain legal consequences. If the uprising leads to the establishment of a new government or state, international law does not provide a forum for examining the legality of its genesis, but leaves the international community to recognise the right to freedom of the new entity.

The right of peoples to self-determination, at least since the eighteenth century the American Revolution or the nineteenth century Spring of Nations in Europe, remained acceptable in international relations as a political fact, a fact of universal significance. After World War II, the right of peoples to self-determination was codified in international agreements and resolutions of the UN General Assembly with a strong emphasis on self-determination of colonial peoples, which does not change the fact that the right of peoples to self-determination is a universal right of all peoples and nations of the modern world.

In the context of trafficking in arms and military technologies and other types of arms transfer, it can be stated that the transfers that support the universal right of peoples to self-determination, even if it means supporting the military effort of the peoples and nations in a war of national liberation, are legal in the light of the purposes and principles of the Charter of the United Nations.

Recognising the power of the universality of the principle of self-determination of nations, we must agree with the position that it cannot be regarded as an assault on the use of force for the realisation of the right of self-determination (national liberation war). In the same way, an act of support for the people, the people fighting for their independence, cannot be prohibited. If, therefore, the action in favour of self-determination is legal, illegal activity becomes opposed to this trend.

Another goal mentioned in the Charter of the United Nations is to solve, through international cooperation, international problems of an economic, social, cultural 
or humanitarian character, as well as the promotion of human rights and to encourage respect for these rights and fundamental freedoms for all, without distinction as to race, sex, language or religion.

The above-mentioned goal can be summarised in such a way that it shows two concurrent and complementary demands: to solve problems experienced by human societies in the world and respect for human rights.

Due to the separation among the rules of the trade in arms and military technologies and the individual principle of respect for the rule of humanitarian law and human rights, this issue will be further discussed in a separate section (see section 6).

\section{The principle of transparency in the transfer of weapons and military technology}

The principle of transparency remains a key instrument for building confidence and security between states. The principle is expressed by all the basic international documents regulating the circulation of arms and military technology. Transparency of armaments and military force allocation was given a lot of attention in the CSCE/OSCE aimed at building international confidence and security in an era of escalating military tension between nuclear powers. The aim of the 1973 Conference on Security and Cooperation in Europe was to take all the issues related to European security, including political, military, economic, scientific - technical, ecological and humanitarian security issues. ${ }^{12}$

In these deliberations, we will be interested in two aspects of military security implemented in the framework of the CSCE/OSCE: increasing transparency as to the intentions and military capabilities and the implementation of the reduction of military equipment and personnel. Within the framework of the CSCE, instruments that were used to build trust and international security have been developed. In the catalogue of these instruments, we can include the Treaty on

12 See R. Zięba, Funkcjonowanie paneuropejskiego mechanizmu bezpieczeństwa KBWE/ OBWE, Studia Europejskie nr 3/1998, p. 85. 
Conventional Armed Forces in Europe (CFE signed on November 19, 1990), the Final Act on Personnel Strength of Conventional Armed Forces in Europe (CFE 1A signed on July 10,1992), the Treaty of Open Skies (signed on March 22, 1992) and developed in several stages (Stockholm from 1984 to 1986 r., Vienna 1990 and 1992) and the so called international confidence and security building measures such as:

The international confidence and security building measures also include the principle of mutual information on transfers of weapons and military technologies. On November 24, 2000, the OSCE adopted the "Document on Small Arms and Light Weapons"13, which established a regime for exchange of information on transfers of such weapons made by OSCE participating States. The regime corresponds in its assumptions to the standards adopted by the UN in the framework of the Register of Conventional Arms.

The principle of transparency in the trade of weapons and military technology is supported by a number of independent control regimes. Firstly, the internal regimes of state indicating the licensing by state business enterprises operating in the military trading sector and the special obligation of reporting transfers of weapons by entrepreneurs. Secondly, the states (including Poland) transmit summary information about the transfers that have taken place and refusals of such transfers in the framework of the obligations of membership in the UN, the $\mathrm{EU}$, the OSCE, and the Wassenaar Arrangement.

Based on article 27a, para. 1. of the Act of November 29, 2000, on foreign trade in goods, technologies and services of strategic importance for national security and for the maintenance of international peace and security, domestic arms exporters are required to submit a report on the actual performance of exports in the previous year to the Minister of Foreign Affairs by the end of April every year.

On the basis of UN General Assembly Resolution No. 46/36, states shall report annually with data on exports, imports, and the holding of eight categories of offensive conventional weapons, including optional light weapons.

13 See FSC.JOUR/314, the material available at the Internet address: http://www.osce. org/fsc/20783. 
Countries participating in the Wassenaar Arrangement exchange information on the sale of arms to third countries. Export notifications are made twice a year, based on Wassenaar Arrangement checklists modeled on checklists from the UN Register of Conventional Arms. States give information about the refusals to export weapons and dual-use goods and undertake consultation when the request for authorisation to transfer a similar weapon is being examined by another state.

EU countries are required, in accordance with the Council Common Position No. 2008/944/CFSP of December 8, 2008 defining common rules governing the control of exports of military technology and military equipment, to prepare information on the export of weapons and military technology once a year. The collected data is then published by the $\mathrm{EU}$ in the form of the "Annual report concerning the European Union. Arms exports." ${ }^{14}$. The necessity of reporting the state arms export is confirmed by art. 27c. of the Act of November 29, 2000, on foreign trade in goods, technologies and services of strategic importance for national security and for the maintenance of international peace and security: "1. The minister responsible for foreign affairs shall prepare an annual report on arms exports, which shall inform the competent authorities of the Member States of the European Union by the end of the third quarter of next year".

Specific measures of transparency have also been provided for in art. 7 of the Ottawa Convention of September 18, 1997. In this article, each state party to the Convention was required to submit to the Secretary General of the UN report containing information on the total number of its landmines, divided into types, numbers and lot numbers of each type of anti-personnel mine owned, as well as information about the number and types of mines destroyed as a result of the implementation of the Ottawa Convention. Countries were required to annually update the abovementioned information by 30 April each year.

14 See www.msz.gov.pl/pl/polityka_zagraniczna/polityka_bezpieczenstwa/kontrola_eksportu/ transparencja/transparencja;sessionid=36A51C201162AEB978C304DF7244F01F.cmsap1p. 


\section{The principle of limitation of armaments as a factor constituting a threat to peace and national, regional and international security}

The principle of limitation of armaments as a factor constituting a threat to peace and national, regional and international security was expressed in the document of the CSCE: "The principles of trade in conventional arms" of November 25, 1993, in its paragraph 4, point d): "The participating States reaffirm their strong belief that excessive and destabilising accumulation of weapons is a threat to national, regional and international peace and security.. The principle is also confirmed in the "Document on Small Arms and Light Weapon" adopted in 2000 at the OSCE. In paragraph 3 (ii) of that document we can read: "In particular, the Participating States commit themselves to contribute to the reduction, and prevention of, the excessive and destabilising accumulation and uncontrolled spread of small arms, taking into account legitimate requirements for national and collective defence, internal security and participation in peacekeeping operations under the Charter of the United Nations or in the framework of the OSCE...

The Joint Action of the Council of July 12, 2002, on the European Union's contribution to combating the destabilising accumulation and spread of small arms and light weapons and repealing Joint Action 1999/34/CFSP is entirely devoted to combatting excessive accumulation of weapons as a factor threatening international peace and security.

The Joint Action of the Council of the EU is focused on the negative accumulation of small arms and light weapons, which in contemporary conditions and territorially limited armed conflicts of a hybrid character is an essential tool in the fight. The easy availability of such weapons, primarily due to their low cost, durability and ease of use make small arms and light weapons easy to obtain and use. On the one hand, excessive accumulation of such weapons could escalate tension and ultimately lead to the outbreak of armed conflict; on the other hand, because of their durability, such weapons are used for many years after the end of an armed conflict endangering the internal security of the state and security in the region. The excessive accumulation of small arms and light weapons in the hands of groups not controlled by the state after the end of armed conflict often 
causes political instability in post-conflict countries by preventing their normal functioning and development.

The European Union declared appropriate assistance to countries in need of support in eliminating surplus small arms and light weapons and their ammunition, especially where it could prevent armed conflict or in post-conflict situations. The EU has also committed to promoting confidence-building measures aimed at the voluntary laying down of surplus arms and light weapons along with ammunition, the demobilisation of combatants and their subsequent rehabilitation and reintegration into society. It declared support activities include compliance with peace and arms control, human rights, and the principles of humanitarian law, to protect the rule of law, especially with regard to the personal safety of former combatants and small arms amnesties, as well as local development projects and other economic and social incentives. The EU also expressed its willingness to help in the effective removal of surplus small arms and light weapons and their ammunition through the safe storage as well as the quick and effective destruction of these weapons and ammunition.

\section{The principle of regulating transfer of arms and military technologies in the domestic law of states}

The principle of regulating transfer of arms and military technologies in domestic law means the need to establish specific legislation relating to the problems of production, storage, and the international transfer of weapons and ammunition at the level of the internal legal systems of the countries. This principle is an explicit demand for the operation of international law; the specificity is the conclusion in the interstate agreements of only general obligations for the parties (states) of a specific behaviour. The practical implementation of this kind of international obligation requires the most appropriate adjustment of internal legislation, which is the direct basis for the actions of the state bureaucratic apparatus.

International agreements which are the primary source of international law in principle apply to part of those agreements. State parties are responsible for the proper realisation of the contract terms to other countries that are also committed 
to a specific maintenance. As a rule, such agreements between countries do not produce direct effects on nationals, but only on the countries themselves as parties to an international agreement. In other words, the agreement does not produce a direct effect in relation to nationals of parties and it means that citizens cannot rely on the international agreement as a direct basis for their claims against the state (today, this principle has been weakened due to the growing international legislation in the field of human rights protection). Of course, in accordance with the relevant provision of the Constitution, ratified international agreements, after the relevant notice, became a source of universally binding law in the Republic of Poland. The condition of direct application in a particular situation to particular individual provisions of an international agreement is appropriate from a technical point of view, i.e. the sufficiently precise wording of the contract. Otherwise, the general provision of the international contract requires clarification in national legislation and, in itself, cannot constitute a basis for decision in a particular case, to a single person.

The principle of regulating transfer in arms and military technology in domestic law requires that the state set detailed rules relating to licensing production and trade by the state in their internal legislation, indicating the state authorities competent in the field of licensing and control of this production and trade and the authorities responsible for international cooperation and exchange of information. This principle stems from the simple observation that only countries have adequate administrative capacity and logistics in the form of organs, inspection services and to effectively implement and monitor the production and transfer of all kinds of weapons, explosives, and dual-use materials. The effectiveness of the provisions contained in international agreements depends on their implementation at the level of state legislation.

\section{The principle of respect for the rules of humanitarian law and human rights}

In the key international documents regulating the circulation of arms and military technologies, we can find a number of references to respect for human rights. The broadest reference to this issue is the European Union document from 
1998: "Code of Conduct on arms exports,", which says that EU member states are obliged to refrain from exporting arms that could be used for internal repression against the civilian population, such as torture and other cruel, inhuman or degrading treatment or punishment, summary or arbitrary executions, enforced disappearances, arbitrary detentions and other serious violations of human rights and fundamental freedoms set out in relevant international human rights instruments, including the Universal Declaration of Human Rights and the International Covenant on Civil and Political Rights. EU member states are required to assess the attitude of the recipient country's military hardware towards relevant principles established by international human rights instruments and to refuse the allocation of an export license if there is a clear risk that the planned exports could serve internal repression. They also have a duty to take particular care in the allocation of export licenses (taking into account the nature of the exported military equipment) to countries for which serious human rights violations have been established by the competent bodies of the United Nations, the Council of Europe or the European Union.

The CSCE document: "The principles of trade in conventional arms" of November 25,1993 , states that the countries exporting military equipment should take into account respect for human rights and fundamental freedoms in the recipient country and to refrain from exporting weapons which could be used to violate these rights and freedoms.

The Arms Trade Treaty of 2013 says that peace and security, development and human rights are a pillar of the United Nations system and the foundations of collective security and these values are interdependent and mutually reinforcing.

State Parties to the Arms Trade Treaty undertake to respect the rules of human rights, including those listed in the United Nations Charter and the Universal Declaration of Human Rights.

One of the documents adopted within the framework of the Wassenaar Arrangement on December 3, 1998, entitled "Elements for objective analysis and advice on the potentially destabilising accumulations of conventional arms" states that countries should consider when trading weapons and military technologies, if the military equipment is likely to be used as a tool for violations of human rights and fundamental freedoms, and the law of armed conflict. 
In the Polish Act of November 29, 2000, on foreign trade in goods, technologies and services of strategic importance for national security and for the maintenance of international peace and security, we can find a statement that the trade control authority (the minister in charge of economy) has obliged to refuse the authorisation for transfer of weapons if there is a risk that the equipment to be exported might be used for internal repression or acts constituting violations of international humanitarian law. At the same time, the trade control authority may refuse to grant authorisation for transfer of weapons if it is likely to have a negative impact on respect for human rights in the country of the end user (art. 16 of the Act). In addition, pursuant to art. $6 \mathrm{~b}$ of the cited Act, the Council of Ministers received the power to issue a regulation determining the list of countries with which trade in the strategic goods are prohibited or restricted because of public safety and human rights.

As mentioned in the Charter of the United Nations, the goal of promoting human rights and encouraging respect for these rights and fundamental freedoms carries with it a demand to promote and disseminate the concept of human rights among the UN member states and those that are outside the UN system. In the fundamentals of this formulation is another idealistic belief that there is a catalogue of universal rights, inherent, inalienable and natural belonging to all people of the world regardless of gender, race, religion, nationality or lack thereof. This is another example of the naive, Eurocentric thinking resulting from lack of knowledge and understanding of different cultures and mechanisms governing the behaviour of human societies. Human rights are in fact essentially a catalogue of civil rights guaranteed by the democratic state to its citizens and to a limited extent to other people staying in their territory. The category of civil rights emerged in the Euro - Atlantic culture in the eighteenth century on the wave processes that led to the American Revolution (also known as the War of Independence of the United States of America) and the French Revolution, which ended the Western countries feudal period based on the class division of society. The French Revolution, which is the reference point for the processes that have shaped modern Western culture, was essentially a bourgeois revolution, a revolution directed against the politically privileged layer of the aristocracy with the monarch at the head. The driving force behind changes in the eighteenth - century Europe was enrichment by the exploitation of the overseas colonies layer of the bourgeoisie, but without real influence on the policies of the state 
and ways of spending its resources. There has been a shift in the sources of prosperity. In feudal conditions, the basis of wealth and power was the possession of land, which allowed agricultural production that constituted the main branch of the economy of the state in the pre-industrial period. In connection with the development of trade (intensified through colonial conquest) and industry (based on new inventions and technologies of the Enlightenment), there was a change in the economic structure of feudal state and shifting sources of prosperity with soil ownership to have capital, which was shared with landless burghers who performed activities in trade, shipping and manufacturing (industrial production). However, in the wake of the shift sources of prosperity, the allocation of political power did not alter automatically. As a result of social division resulting from the reasons mentioned above, the monarchy was overthrown, the king beheaded and a multitude of aristocrats which guaranteed the status quo and led to the seizure of power by the current tributaries, who overnight became citizens of their own nation-state. The nation was not immediately perceived as a community of citizens, but rather as a community of people of a certain status, financial standing, related to the possession of political rights.

The above mentioned phenomena, processes and events took place in the area of Euro - Atlantic culture, which led to this, and no other configuration of this culture. The resultant social and economic processes that took place in the Euro - Atlantic culture over the last few centuries led to the formation of the modern model of a democratic state with its foundation on the rights of citizens called human rights. The tendency to name the rights of citizens was formed in Europe in the era of the French Revolution and these universal, natural and inalienable human rights have their origin in the expansion and domination of the European colonial metropolis. Non-European cultures that have their own historical experience on the basis of which their internal social and political systems developed and do not necessarily have to accept solutions developed in the Euro - Atlantic culture. In particular, the egalitarian ideaof equality before the law for men and women, so naturally present in Western culture, is not acceptable for Muslim culture, in which male and female roles in society are diverse. It should also be honestly noted that the Euro-Atlantic idea of equality for women is a relatively new idea dating back to the first half of the twentieth century. It is widely known, however, that among the material conceptions of justice, the idea that "everyone is the 
same" is only one of many criteria for the allocation of rights and duties assigned to the unit in society. ${ }^{15}$

The Euro - Atlantic powers, by working out the scientific, technological, military and economic potential, managed to impose a vision of social order, political system, international order, and, thus, a model of law (domestic and international) on the rest of the world. Therefore, the idea of the need for universal standards of human rights seems to be widely accepted today in the international community. This is due to the fact that the tone of discussion in the international arena is still set by European powers.

Thus, it remains irrefutable the idea of respect for the trade in arms and military technologies is a human right and fundamental freedom.

\section{Bibliography}

Barber B., If Mayors Ruled the World: Dysfunctional Nations, Rising Cities, Yale University Press 2013 (Polish edition: Gdyby burmistrzowie rzadzili światem, Wydawnictwo Muza S.A. 2014).

Florida R., The Rise of the Creative Class and How It's Transforming Work, Leisure, Community and Everyday Life, Basic Books Publishing House 2002, (polish edition: Narodziny klasy kreatywnej, Wydawnictwo Narodowe Centrum Kultury 2010). Glaeser E., Triumph of the City, Macmillam Publishing House 2011.

Maslow A., A Theory of Human Motivation, Psychological Review, 1943, Vol. 50/4.

Pietraś Z. J., Podstawy teorii stosunków międzynarodowych, UMCS, Lublin 1986.

Symonides J. (ed.), Wydawnictwo Naukowe Scholar, Warsaw 2010.

Zięba R., Funkcjonowanie paneuropejskiego mechanizmu bezpieczeństwa KBWE/OBWE, Studia Europejskie nr 3/1998.

Zięba R., O tożsamości nauk o bezpieczeństwie, AON Scientific Papers, No. 1 (86) 2012, ordinance of Council of Ministers dated October 4, 2010 r. (Journal of Laws. 2010. No. 198, item. 1314).

15 We can also indicate other demands expressing different concepts of justice, "to each according to his works", "to each according to his merits "',to each according to his needs", "to each according to his position",etc. 
http://www.msz.gov.pl/pl/polityka_zagraniczna/polityka_bezpieczenstwa/kontrola_ eksportu/transparencja/transparencja;jsessionid=36A51C201162AEB978C304DF72 44F01F.cmsap1p.

http://www.osce.org/fsc/20783.

Ordinance of Council of Ministers dated October 4, 2010 r. (Journal of Laws. 2010. No. 198, item. 1314).

Statute of the International Criminal Court of July 17, 1998, http://legal.un.org/icc/ statute/romefra.htm.

UN General Assembly Resolution of December 14, 1974 (RES 3314/1974). 